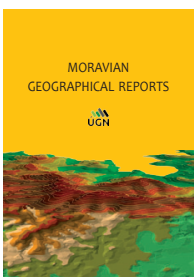

MORAVIAN GEOGRAPHICAL REPORTS

The Czech Academy of Sciences, Institute of Geonics

journal homepage: http://www.geonika.cz/mgr.html

doi: https://oi.org/10.2478/mgr-2021-0002

\title{
Public transport accessibility to upper secondary schools measured by the potential quotient: The case of Kraków
}

\author{
Piotr ROSIK ${ }^{\text {a }}$, Sabina PUŁAWSKA-OBIEDOWSKA ${ }^{\text {b }}$, Sławomir GOLISZEK ${ }^{\text {a }}$
}

\begin{abstract}
The spatial differences in public transport accessibility to upper secondary schools are examined in this article, using the potential accessibility model, and based on the example of the city of Krakow. In order to achieve this goal, the potential quotient index has been used, taking into account both the demand for educational services operationalised with the population aged 15-19, and the supply of services depicted by the supply of places for pupils in different types of upper secondary school. A supplementary objective is to present recommendations for transport and educational policy implemented in the city in the context of potential locations of new upper secondary schools based on, among other parameters, the mean centre of the potential accessibility distribution and the potential accessibility dispersion index. We conclude that to better balance access to different types of schools throughout the city in the future, a new location for a general upper secondary school could be considered in the southern or eastern parts of Kraków.
\end{abstract}

Keywords: Potential accessibility, school accessibility, potential quotient, accessibility dispersion, Kraków, Poland

Article history: Received 25 March 2020, Accepted 30 October 2020, Published 31 March 2021

\section{Introduction}

Access to services of general interest, including access to educational services at various levels of education, has been an issue analysed by researchers around the world in a variety of contexts. Some authors refer to the concept of social justice which is invoked as a basis for creating broad and equal access to education, including equal access in spatial terms (Cave and Chester, 1981; Pacione, 1989). Spatial variation in the demand for and the supply of education services, measured by the potential model, enables one to produce recommendations concerning possible new locations for schools (Department for Transport, 2005). This is particularly important for upper secondary schools which have neither a local (primary schools) nor regional (universities) catchment area. The catchment area for upper secondary schools is mainly the city itself, possibly extended to its immediate vicinity (Guzik, 2003a; Walaszek, 2016; GUS, 2018).

The relatively small number of accessibility studies concerning access to medium-level education facilities could be the result of scientists showing little interest in the pre-working age group. This group is already independent and does not need to be escorted, but it is still outside the labour market. At least, in the countries and regions of Central and Eastern Europe, which have similarly shaped population pyramids, there are only a few valuable exceptions in relation to analyses of accessibility to schools (Guzik, 2003a, 2003b; Walaszek, 2006; Biosca, Spiekermann and Stępniak, 2013; Zelinsky and Kubak, 2014; Kučerová, Bláha and Kučera, 2015). There is, then a certain research gap in this field of research in relation to this part of the continent. The result of insufficient accessibility research is that recommendations for school locations at city level are usually implemented in an intuitive way, as proposals by local communities to city authorities demanding the construction of educational facilities. Nevertheless, this is usually related to a lower level of the education system, i.e. primary schools. In the case of upper secondary schools, new school facilities are created for various reasons, including the development of new housing estates, an influx of young migrant families, in particular in Western Europe. In Poland there were educational reforms, after which new upper secondary schools were created in Kraków, the city under examination in this study.

The main goal of the paper is to analyse the spatial differences in public transport accessibility to upper

\footnotetext{
${ }^{a}$ Institute of Geography and Spatial Organization, Polish Academy of Science, Warsaw, Poland (*corresponding author: P. Rosik, e-mail: rosik@twarda.pan.pl)

${ }^{\mathrm{b}}$ Faculty of Civil Engineering, Cracow University of Technology, Krakow, Poland
} 
secondary schools using the potential accessibility model. In order to achieve this goal, the potential quotient index has been used, taking into account both the demand for educational services operationalised with the population aged 15-19 and the supply of services represented by the supply of places for pupils in different types of upper secondary school in the city of Kraków. A supplementary objective is to present recommendations for the transport and education policy adopted in the city in the context of potential locations for new upper secondary schools based, among other parameters, on the mean centre of the potential accessibility distribution and the potential accessibility dispersion index.

The novelty of this paper lies in the use of the potential quotient index, the mean centre of public transport accessibility distribution and the potential accessibility dispersion index as potential tools for planners concerning decisions on possible locations for new upper secondary schools of a particular type in the city in a period of demographic change.

The paper is made up of six sections. The second section presents a survey of literature on methods of measuring the accessibility of educational services. In the third section we describe our study area. The fourth section is devoted to the detailed methodology we use in the paper. In the fifth section we discuss the results and in the sixth section conclusions are drawn.

\section{Methods of measurement of the accessibility of educational services}

It is very difficult to identify an approach to accessibility which is the most appropriate from among the range of possibilities available. As Gould (1969, p. 64) indicates: "Accessibility... is a slippery notion... one of those common terms that everyone uses until faced with the problem of defining and measuring it". Despite the lack of a single definition, the concept of accessibility has been developed for many decades, and researchers, depending on the purpose of their projects, have proposed different approaches to it (Geurs and van Wee, 2004). Johnston, Gregory and Smith (1994) formulate the definition of accessibility as "the ease with which people can reach desired activity sites". They also propose three elements that should be included in accessibility analysis. In relation to the topic of this paper, these are: (1) the location of the point from which the accessibility is measured, usually places of residence; (2) the characteristics of the transport system, for example the public transport system; and (3) the location of the activities for which this accessibility is measured, for example secondary schools.

Usually the concept of transport accessibility is used in research and practice to support spatial and transport planning processes by evaluating development strategies at various scales, including Transit Oriented Development scenarios (Geurs, Zondag, de Jong and de Bok, 2010; Litman, 2008; Gulhan, Ceylan, Özuysal and Ceylan, 2013; Qviström, 2015), as well as supporting policies to guarantee high-quality public services (Stępniak, Pritchard, Geurs and Goliszek, 2017; Stępniak and Rosik, 2016). More recent research projects use accessibility in studies of the relationship between transport, social exclusion and other aspects of equity in transport (Tsou, Hung and Chang, 2005; van Wee and Geurs, 2011; Lucas, 2012; Martens, 2012; Pritchard, Moura, Silva and Martinez, 2014; Manaugh,
Badami and El-Geneidy, 2015; Stępniak and Goliszek, 2017). Some authors have also applied the concept of accessibility to express and describe relationships between urban structure and transport behaviour (Scott and Horner, 2008; Szarata, 2013).

On the basis of a literature survey (Geurs and van Eck, 2001), one can identify different groups of methods of accessibility measurement:

1. infrastructure-based accessibility measures, using infrastructure development indicators, such as the quantity and quality of infrastructure;

2. distance-based accessibility measures (travel-cost accessibility), i.e. accessibility measured by the physical, temporal or economic distance to a set of destinations;

3. isochronic-based accessibility measures (cumulative accessibility), i.e. accessibility measured by determining a set of destinations accessible within a specific distance, time, cost or effort;

4. person-based accessibility measures, analysing accessibility at the individual level; and

5. potential-based accessibility measures, which is the most popular method and the one used in this paper.

\subsection{Potential accessibility}

Modelling of potential accessibility has been well known since the work of Hansen (1959), who was a forerunner in this field and who defined accessibility as the "potential of opportunities for interaction". In general, potential accessibility is measured by the number of activities (opportunities) reachable within a certain distance, time or cost. The closer and greater the opportunity, the more it contributes to accessibility. The potential model is very sensitive to the particular distance decay function that is used (see Stępniak and Rosik, 2018; Rosik, Pomianowski, Komornicki, Goliszek, et al., 2020; and Goliszek, Połom and Duma, 2020).

Potential accessibility is described by the general formula:

$$
A_{i}=\sum_{i} O_{j} F\left(t_{i j}\right)
$$

where $\mathrm{A}_{i}=$ potential accessibility of transport zone $i$; $\mathrm{O}_{j}=$ opportunity (attractiveness) of transport zone $j$; $\mathrm{F}\left(\mathrm{t}_{i j}\right)=$ distance decay function; and $\mathrm{t}_{i j}=$ travel time between transport zones $i$ and $j$.

\subsection{Accessibility components}

Geurs and Van Wee (2004, p. 128) defined accessibility as "the extent to which land-use and transport systems enable (groups of) individuals to reach activities or destinations by means of a (combination of) transport mode(s)." Therefore, one can select four components affecting the level of accessibility, which are transport, land-use, temporal and individual factors (Geurs and van Eck, 2001; Geurs and van Wee, 2004). Assuming that the attractiveness of the travel destination is measured by the number of places in secondary schools, the four accessibility components have the following characteristics described in the last column in Table 1.

Any changes in the assumptions lying behind the components mentioned in Table 1 can significantly affect the results of accessibility analyses. In the case of the transport component and public transport, one can take into account many factors determining the functioning of public transport - related both to the linear and point infrastructure, 


\begin{tabular}{|c|c|c|}
\hline $\begin{array}{l}\text { Accessibility } \\
\text { component }\end{array}$ & Characteristics & $\begin{array}{l}\text { Access to educational services, } \\
\text { in particular upper secondary schools - } \\
\text { selected characteristics }\end{array}$ \\
\hline \multirow[t]{3}{*}{ Transport } & $\begin{array}{l}\text { Connected to the transport system, which provides the } \\
\text { user with the option of travelling between the origin and } \\
\text { the destination using specific means of transport. It can } \\
\text { be expressed by the: }\end{array}$ & $\begin{array}{l}\text { Public transport as the dominant means of } \\
\text { transport. }\end{array}$ \\
\hline & $\begin{array}{l}\text { (1) total travel time (including travel time, waiting } \\
\text { time and parking time), cost and effort (e.g. reliability, } \\
\text { comfort level, risk of accidents) as elements of the } \\
\text { distance decay function; }\end{array}$ & $\begin{array}{l}\text { High value assigned to travel time as a } \\
\text { nuisance factor by young people. Significantly } \\
\text { lower importance of cost (pupils usually use } \\
\text { discounted tickets) and comfort. }\end{array}$ \\
\hline & $\begin{array}{l}\text { (2) supply of the transport system including } \\
\text { infrastructure, frequency, location of stops and tariffs, } \\
\text { as well as demand created by the users of individual and } \\
\text { public transport. }\end{array}$ & $\begin{array}{l}\text { A clear indication of accessibility as one of } \\
\text { the most important factors and criteria for } \\
\text { selection of the facility. }\end{array}$ \\
\hline Land-use & $\begin{array}{l}\text { The land use component reflects the land-use system, } \\
\text { including the spatial distribution of opportunities } \\
\text { (Geurs and van Wee, 2004) and is related both to the } \\
\text { supply of opportunities and their location, as well as the } \\
\text { demand for these opportunities created in the location } \\
\text { of origin (e.g. residential areas). This component can be } \\
\text { reflected by juxtaposing supply and demand, then the } \\
\text { effects of competition are mapped (van Wee, Hagoort } \\
\text { and Annema, 2001). }\end{array}$ & $\begin{array}{l}\text { Accessibility is conditioned by changes in city } \\
\text { structure and the demographic development of } \\
\text { individual districts. } \\
\text { Spatial variation in supply and demand is a } \\
\text { prerequisite for the location of potential new } \\
\text { facilities. }\end{array}$ \\
\hline Temporal & $\begin{array}{l}\text { This is related to time constraints, i.e. the level of } \\
\text { accessibility depending on the time of day or week, or } \\
\text { the time in which users perform certain activities. }\end{array}$ & $\begin{array}{l}\text { Participation in school activities, usually at } \\
\text { certain times of the day. } \\
\text { A clear morning and afternoon peak. }\end{array}$ \\
\hline Individual & $\begin{array}{l}\text { Illustrating individual users or groups of people in the } \\
\text { context of their needs, abilities and other socio-economic } \\
\text { determinants (such as age, income, education level). } \\
\text { These features have a significant impact on transport } \\
\text { users and their choices (e.g. possession of a car, driving } \\
\text { licence, skills and education in finding a school or a job } \\
\text { in the vicinity of one's place of residence, etc.). }\end{array}$ & $\begin{array}{l}\text { A clearly defined age of travellers: } 15-19 \text { years. } \\
\text { Frequent lack of possession of a driving licence, } \\
\text { which determines a very large share of the } \\
\text { usage of public transport in this age group. }\end{array}$ \\
\hline
\end{tabular}

Tab. 1: The four components of accessibility with selected characteristics relating to access to upper secondary schools. Source: authors' conceptualisation

rolling stock and quality features of the transport service. Among all the travel destinations (land-use component) for which accessibility analyses are carried out, the most common are jobs (e.g. Geurs and van Eck, 2001; Cheng and Bartolini, 2013; Östh, Lyhagen and Reggiani, 2016), shopping locations (e.g. Widener, Farber, Neutens and Horner, 2013; Pashkevich and Puławska, 2016; Niedzielski and Kucharski, 2019), health care facilities (e.g. Goddard and Smith, 2001; McGrail, 2012), and other facilities related to leisure or entertainment (Scott and Horner, 2008; Dony, Delmelle and Delmelle, 2015). Some of the accessibility studies also take into account different educational facilities (see Tab. 2).

In general, the concept of the accessibility of education was used in a dynamic way to identify spatial variation in the accessibility of education within the special context of transition in post-socialist countries (Guzik, 2003a, 2003b; Walaszek, 2006; Kučerová, Bláha and Kučera, 2015; Stępniak, Pritchard, Geurs and Goliszek, 2017). Different methods have been applied in determining the accessibility of schools, including competition effects, among them the two-step floating catchment area (hereinafter '2SFCA'), location quotient, and potential quotient. Most of the works emphasise the role of access to schools in making decisions about their choice. Accessibility, understood as proximity to place of residence, is one of most frequently mentioned aspects taken into consideration during the selection of secondary schools (GUS, 2013; Walaszek, 2006). More recent work on educational accessibility also focuses on equity issues, and combines the spatial pattern of schools together with socio-demographic and economic variables in order to assess ongoing policies considering centralisation or other changes to the educational system (Thelin and Niedomysl, 2015; Gao, He, Liu, Zhang, Wang and Cai, 2016; Lee and Lubienski, 2017; Moreno-Monroy, Lovelace and Ramos, 2018; Ye, Zhu, Yang and Fu, 2018).

\subsection{Potential quotient (PQ)}

The most general form of the school accessibility model is represented by the potential model with the inclusion of the competitiveness factor. As Geurs and van Eck (2001) point out, the effects of competition on opportunities may be incorporated in an accessibility model by dividing the supply potential by the demand potential. Therefore, the indicator can be interpreted as the distribution of potential for satisfying demands as a function of the intensity of these demands (Czyż, 2002). The $\mathrm{PQ}$ is a variable with a continuous spatial distribution (Czyż, 2002), allowing for visual 'smoothing' of differences in the distribution of opportunities between neighbouring regions. $\mathrm{PQ}$ solves many problems which arise when the potential measure is employed (e.g. values at the edges of the study area or the level of friction quotient, etc. because in $\mathrm{PQ}$ they are being reduced). The indicator is particularly useful for estimating the accessibility of job opportunities (Weibull, 1976) or general practitioners (Knox, 1978). Nevertheless, it can also be used for modelling accessibility to secondary schools 


\begin{tabular}{|c|c|c|c|c|}
\hline Author(s) & Case study & Type of school & Research goal & Methods \\
\hline $\begin{array}{l}\text { Williams and Wang } \\
\text { (2014) }\end{array}$ & $\begin{array}{l}\text { Metropolitan area White } \\
\text { flight, Baton Rouge } \\
\text { Metropolitan Statistical } \\
\text { Area, Louisiana, USA }\end{array}$ & High schools & $\begin{array}{l}\text { Verification of differences } \\
\text { in the level of accessibility } \\
\text { of high schools in the } \\
\text { metropolitan area. }\end{array}$ & $\begin{array}{l}\text { Dynamic analysis using } \\
\text { the 2SFCA method }\end{array}$ \\
\hline
\end{tabular}

Thelin and Niedomysl Halmstad Region, Sweden Upper secondary (2015)

Kučerová, Bláha and Kučera (2015)

Gao, He, Liu, Zhang, Wang and Cai (2016)

Moreno-Monroy, Lovelace and Ramos (2018)

Sao Paolo Metropolitan region, Brazil

Two rural regions (T

Czech Republic

schools

2873 counties (statistical units), China

Compulsory schools: primary and secondary

Secondary schools

Guzik (2003a) $\quad \begin{aligned} & \text { Małopolska voivodeship } \\ & \text { (including its capital }\end{aligned}$

Krakow), Poland

Secondary schools

Investigation of the

factors that affect choices

about which school to

attend in order to verify

policymakers' belief that

academic quality is the

only factor that influences

students' choices.

Investigation of the impact of development in the primary school sector in

the context of educational policy and management in the Czech Republic.

Analysis of the inequality of compulsory education from the perspective of imbalanced spatial distribution.

Investigation of spatial equity in the provision of public schools together with affordable public transport. Assessment of the current policy of centralisation of public secondary education system.

Dynamic analysis of accessibility to secondary schools in Poland and the Małopolska voivodship in the years of 1950-1998. Verification of the impact of accessibility to education facilities on the education level of residents.

Walaszek (2006) Poznan agglomeration, Poland

Primary, secondary and upper secondary schools

Identification of spatial structure and selected elements of the school network in the Poznań agglomeration.

\section{Ye, Zhu, Yang and Fu \\ Guangzhou, China \\ Secondary schools} (2018)

Spatial patterns of secondary schools and disparities in school accessibility among different social groups at the neighbourhood level.

Lee and Lubienski (2017) Chicago, USA

Public primary schools

Analysis based on address

Stępniak, Wiśniewski, Goliszek and Marcińczak (2017)
Primary, secondary and upper secondary schools
Answering the research questions: how school closures pursued in 2013 , impact on changes to a and how these changes are economic characteristics.

Identification of the spatial variation in the level of a range of public services, including schools. student's access to schools related to community socio-
Empirical survey study, regression analysis

Catchment area analysis, flow analysis

Proximity, cluster analysis, spatial pattern analysis, cold/hot spot analysis

Cumulative opportunities with competition

Proximity, percentage of population, potential quotient

The location quotient was used in order to determine the ratio of demand to supply on the educational market

2SFCA

The change in accessibility is compared with density maps

2SFCA; spatial concentration of high and low levels of accessibility using Local Statistics, Getis-Ord G 
(Guzik, 2003a, 2003b). In this case the number of pupils/ students produces an educational (supply) potential $\left(\mathrm{E}_{\mathrm{i}}\right)$ and the number of school-age individuals produces a population (demand) potential $\left(\mathrm{P}_{\mathrm{i}}\right)$. The form of the equation is as follows:

$$
A_{i}=\frac{D_{i} F\left(t_{i i}\right)+\sum_{j}^{n} D_{j} F\left(t_{i j}\right)}{O_{i} F\left(t_{i i}\right)+\sum_{j}^{n} O_{j} F\left(t_{i j}\right)}=\frac{E_{i}}{P_{i}}
$$

where $\mathrm{D}_{i}, \mathrm{D}_{j}=$ the number of pupils in schools located in the regions $i, j ; \mathrm{O}_{i}, \mathrm{O}_{j}=$ the number of school-age individuals in the regions $i, j ; \mathrm{t}_{i i}=$ internal travel time; $\mathrm{t}_{i j}=$ travel time between $i$ and $j$ transport zones.

\subsection{Potential Accessibility Dispersion (PAD)}

The impact on spatial inequality is measured using the Potential Accessibility Dispersion (PAD) index, which takes into account the standard deviation of the potential accessibility values across all transport zones and the mean accessibility level, using the population aged $15-19$ as the weighting variable (for details see López, Gutiérrez and Gómez, 2008; Ortega, López and Monzón, 2012; Stępniak and Rosik, 2016). The lower the PAD values, the less polarised is the study area in terms of accessibility distribution.

\subsection{Mean centre of potential accessibility distribution}

The spatial distribution of potential accessibility also determines the weighted mean centre, which gives interesting information about the location of the centroid point. In general, the weighted mean centre (geographic centre), is a two-dimensional average weighted by a variable and for accessibility it is calculated according to the following formula:

$$
\bar{x}=\frac{\sum_{i=1}^{n} A_{i}^{(D)} x_{i}}{\sum_{i=1}^{n} A_{i}^{(D)}} ; \bar{y}=\frac{\sum_{i=1}^{n} A_{i}^{(D)} y_{i}}{\sum_{i=1}^{n} A_{i}^{(D)}}
$$

where $\overline{\mathrm{x}}, \overline{\mathrm{y}}=$ centre (centroid); $\mathrm{A}_{i}=$ accessibility of transport zone $\mathrm{i}$ to destination attractiveness $\mathrm{D} ; \mathrm{x}_{i}, \mathrm{y}_{i}=$ coordinates of transport zone $\mathrm{i} ; \mathrm{n}=$ number of transport zones (362).

For this calculation we used the mean centre tool in the QGIS Desktop 3.6.0 application with GRASS 7.6.0.

\section{Study area}

Krakow is the second largest city in Poland, the capital city of Malopolskie Voivodship, an academic and cultural centre, Poland's largest tourist destination (Więckowski and Saarinen, 2019) and one of the richer Polish cities. The territorial development of Krakow occurred through the inclusion of neighbouring areas, particularly Nowa Huta, the easternmost district developed to provide housing for a large steel mill built from scratch in 1951. In 1973, the city limits were extended again and rural areas surrounding the city to the east, south and west were incorporated into it. Krakow is divided into 18 districts.

\subsection{Some aspects of travel behaviour}

For urbanised areas, commuting to schools is identified in a detailed and cyclical manner as part of comprehensive traffic surveys. Commuting to schools (by students) is one of the most important travel motivations in traffic research, usually in second or third place after commuting to work and possibly shopping. This proportion (of all trips) is usually about $12 \%$ of all travel (see Tab. 3). The share of public transport in travel related to education is quite variable depending on the city analysed, and in Poland it varies from $35 \%$ in Gdansk to as much as 51\% in Kraków.

\subsection{Land-use component}

The number of inhabitants of Kraków has remained at a similar level (around 750,000 inhabitants) for a long time, but changes can be observed between districts. The number of residents registered for permanent residence in the innercity districts has been decreasing for years: in the Old Town, Krowodrza and Nowa Huta there was a decrease of about 10 15\% in the period 2009-2016. These districts are inhabited by an aging population, while young and middle-aged people prefer to live in more modern districts of the city. In Kraków many new housing estates are being built and the largest increase in the number of inhabitants has been seen in the southern (Dębniki, Swoszowice and Podgórze) and northern areas (Pradnik Biały) of the city.

This work focuses on the distribution of public and nonpublic upper secondary, following the education system in Poland where upper secondary schools are divided into general upper secondary schools, technical secondary schools, basic vocational schools and other upper secondary schools. In recent years, the number of secondary schools in Kraków has remained at a similar level, with any changes mainly resulting from the reform of the Polish education system. On September 1, 2017, each existing six-year primary school covering grades I-VI became an eight-year primary school covering grades I-VIII, so lower secondary schools, ('gimnazja') ceased to exist, resulting in an increase in the need for places in upper secondary schools, where the

\begin{tabular}{|c|c|c|c|c|c|c|c|c|}
\hline \multirow[b]{2}{*}{ Travel purpose } & \multicolumn{2}{|c|}{ Gdańsk 2016} & \multicolumn{2}{|c|}{ Warsaw 2015} & \multicolumn{2}{|c|}{ Poznań 2013} & \multicolumn{2}{|c|}{ Krakow 2013} \\
\hline & $\begin{array}{c}\text { (to/from) } \\
\text { school }\end{array}$ & $\begin{array}{l}\text { (to/from) } \\
\text { university }\end{array}$ & $\begin{array}{l}\text { home- } \\
\text {-school }\end{array}$ & $\begin{array}{l}\text { school- } \\
\text {-home }\end{array}$ & to school & $\begin{array}{c}\text { to } \\
\text { university }\end{array}$ & $\begin{array}{l}\text { home- } \\
\text {-education }\end{array}$ & $\begin{array}{l}\text { education- } \\
\text {-home }\end{array}$ \\
\hline Share of education trips & $14.40 \%$ & $11.10 \%$ & $6.40 \%$ & $18.20 \%$ & & & & \\
\hline Walking & $40.61 \%$ & $12.53 \%$ & $32.20 \%$ & $35.30 \%$ & $21.20 \%$ & $5.30 \%$ & $38.20 \%$ & $39.30 \%$ \\
\hline Car & $13.38 \%$ & $14.90 \%$ & $16.00 \%$ & $13.90 \%$ & $23.10 \%$ & $18.10 \%$ & $8.80 \%$ & $8.90 \%$ \\
\hline Public transport & $35.13 \%$ & $67.17 \%$ & $49.20 \%$ & $48.00 \%$ & $50.70 \%$ & $72.40 \%$ & $51.40 \%$ & $50.80 \%$ \\
\hline Bicycle & $10.80 \%$ & $5.40 \%$ & $2.20 \%$ & $2.60 \%$ & $2.10 \%$ & $3.80 \%$ & $1.10 \%$ & $0.70 \%$ \\
\hline Other mode & $0.08 \%$ & $0.00 \%$ & $0.40 \%$ & $0.20 \%$ & $3.00 \%$ & $0.30 \%$ & $0.50 \%$ & $0.30 \%$ \\
\hline
\end{tabular}
number of educational years increased from three to four.

Tab. 3: Share of travel related to education and mode in selected cities in Poland. Sources: authors' analysis based on KBRs (Kompleksowe Badania Ruchu [Comprehensive Travel Surveys]) from Gdańsk (KBR in Gdańsk, 2016), Warszawa (KBR in Warsaw, 2015), Poznań (KBR in Poznań, 2013), Kraków (KBR in Kraków, 2013) 
For the purposes of this study, the number of pupils was aggregated into 362 transport zones. At the end of September 2016, 145 upper secondary schools were identified in Kraków according to data provided by the Board of Education in Kraków (SIO, 2016), with nearly 32 thousand pupils attending them. Young people usually choose general upper secondary schools - in 2016 almost 58\% of students took lessons in this type of school. About one third of pupils were taught in technical secondary schools, and about $8 \%$ chose basic vocational schools. The upper secondary school system has a moderate degree of centralisation.

Therefore, pupils who do not live within the city are a minority. Data provided by the Central Statistical Office in Poland indicate that pupils of upper secondary schools commuting or temporarily living in Kraków (e.g. in boarding schools) constitute approximately $10 \%$ of upper secondary school attendance (GUS, 2018). In order to simplify the analysis, such students were not taken into account in calculating accessibility levels.

One can observe an uneven spatial distribution of upper secondary schools within the boundaries of the City of Kraków. Most schools are located in the central part of the city and in Nowa Huta. It is clearly visible that the supply of schools is definitely larger on the northern side of the Vistula in comparison with the southern part of the city, where only a few facilities are located. Nevertheless, accessibility to secondary schools depends not only on their distribution, but also on the spatial relations between schools and their pupils' places of residence, as well as the state of the public transport system.

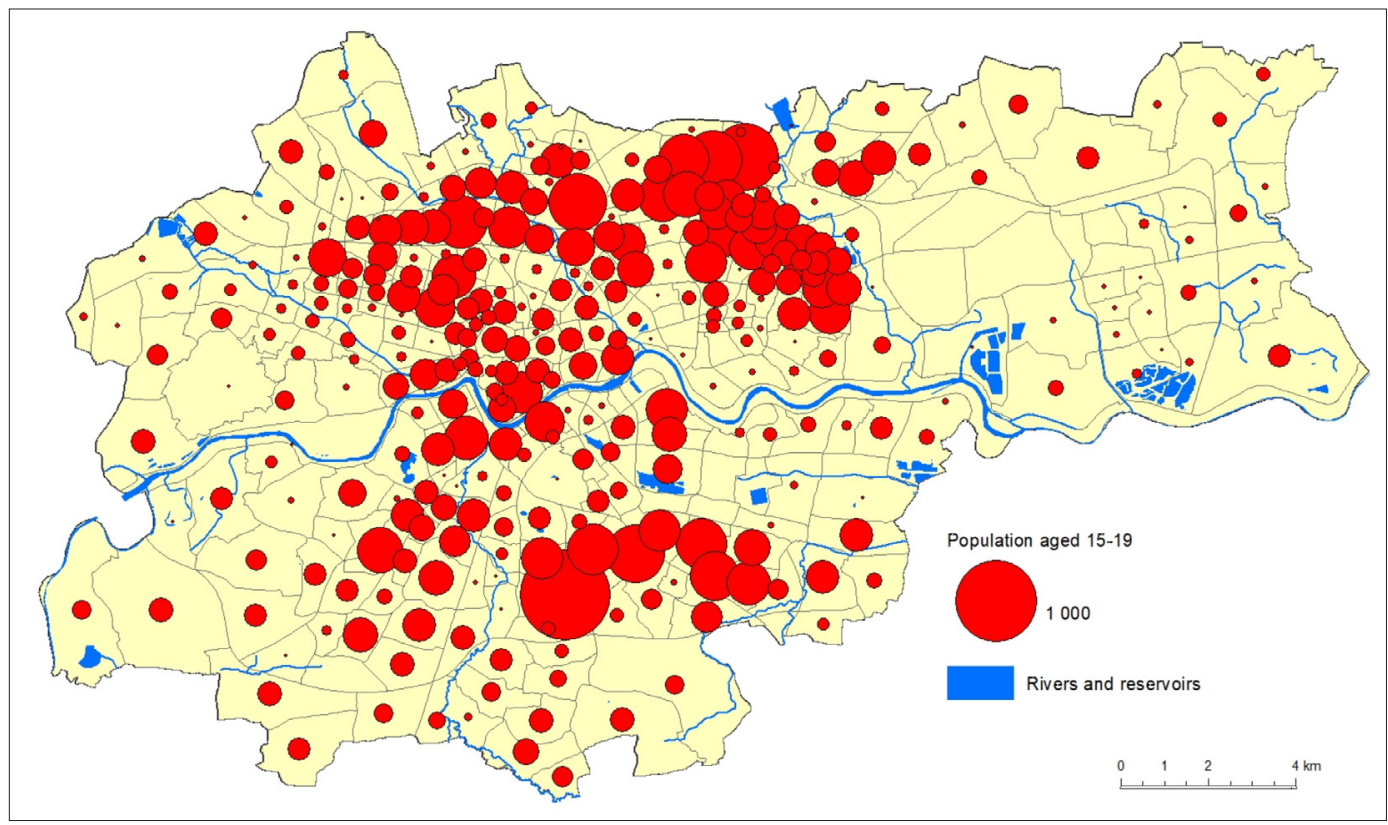

Fig. 1: The number of inhabitants aged 15-19 in 2015

Source: authors' analysis based on demographic data from Imagis. The division into 362 transport zones was based on the existing spatial structure of the city (Szarata, 2014)

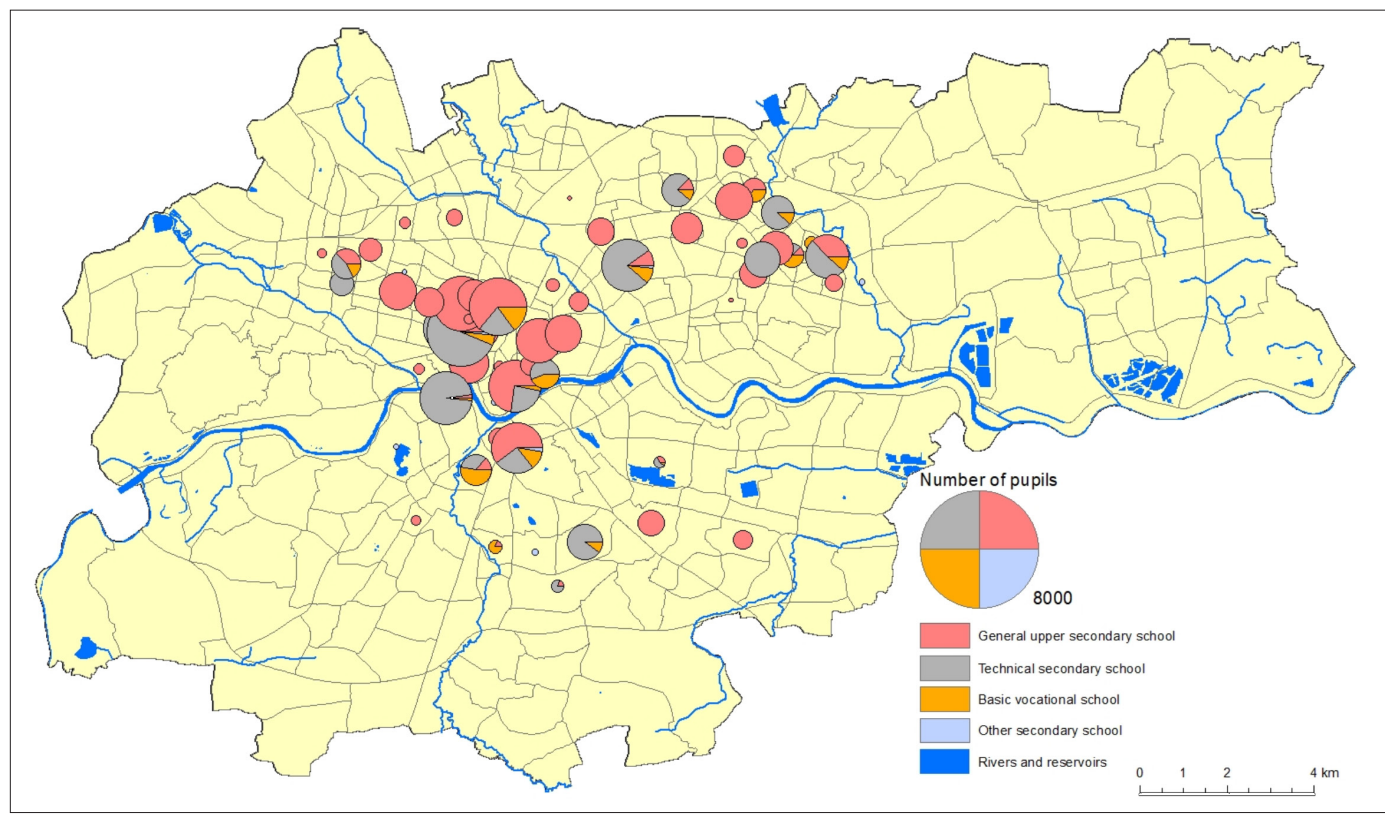

Fig. 2: Distribution of different types of upper secondary school in Kraków (number of pupils in 2016) Source: authors' analysis based on SIO data as of September 30, 2016 


\subsection{Public transport system}

In Kraków there are 27 tram lines and 161 bus lines (including 72 suburban lines: data for 2017). The total length of tram lines is $353 \mathrm{~km}$ and is entirely within the administrative borders of Kraków. The length of bus lines is $2,385 \mathrm{~km}$, of which $1,601 \mathrm{~km}$ is within the Krakow City limits. Figure 3 shows the public transport system in Kraków with additional information about areas with access of less than 5 minutes on foot to the nearest bus or tram stop. The areas of high accessibility (5 minutes walking to the stop) are mainly areas with high density buildings. The additional analysis shows that $90 \%$ of young residents of Kraków (aged 15-19) have access to a bus stop within 5 minutes on foot.

\section{Methods}

The level of accessibility can fluctuate greatly throughout the day as a result of congestion or timetables, and a nonlinear relationship exists between public transport frequency and losses of precision in measuring accessibility (Stępniak, Pritchard, Geurs and Goliszek, 2019). Therefore, to take into account the temporal dimension, in this paper we use the results of a comprehensive travel survey of Kraków (KBR in Kraków, 2013) in which three main purposes of travel were taken into account: commuting to work, travel to school and other travel. According to the results from KBR in Kraków (2013), 50\% of all trips to schools start between 7:00 am and 8:00 am. For this reason, we focus on the morning rush hour and the chosen time at which one gets into public transport, which was used to calculate the level of accessibility, set at 7.00 am resulting in a matrix of travel times between 362 travel zones. For calculations, we use data in the General Transit Feed Specification (GTFS) (see Goliszek, 2021) standard on public transport timetables. We measure accessibility at the centroid of the transport zone. The pedestrian time both to reach the tram or bus stop and to access the internal travel time in formula [2], was determined on the basis of the assumed average speed of access which equals $4.82 \mathrm{~km} / \mathrm{h}$.

In order to estimate the distance decay function, we use a sample of 1,471 home-school-home trips carried out by public transport within the boundaries of Kraków (KBR in Kraków, 2013). The process of estimating distance decay functions has been divided into two stages, using the methodology presented in Salze, Banos, Oppert, Charreire et al. (2011) and Skov-Petersen (2001): (1) matching the type of impedance function; (2) determining the parameters of the adopted function. At the stage of looking for functions, tests were made with non-linear and linear regression models that would best reflect the relationship identified (Tiran, Lakner and Drobne, 2019). In the process of searching for the shape and parameters of the distance decay function, a linear regression model was used, and for this purpose the Statgraphics tool was used. We assumed that the probability of the trip was the dependent variable, and the travel time in minutes was an independent variable. The following formula was determined to be the distance decay power-exponential function (see also Halas and Klapka, 2015):

$$
F\left(t_{i j}\right)=\exp \left(-\beta t_{i j}^{2}\right)
$$

where $\mathrm{F}\left(\mathrm{t}_{i j}\right)=$ distance decay function; $\mathrm{t}_{i j}=$ travel time (min); $\beta=$ beta coefficient; $\beta=0.00122876$.

From the analysis of variance resulting from this analysis, a p-value of less than 0.05 was obtained, which means that there is a statistically significant relationship between the variables (share of travel and travel time) at a confidence level of $95 \%$. A quality assessment of the model was made, resulting in a coefficient of determination $\mathrm{R}^{2}=86.79 \%$. The same beta parameter was used both for population potential, as well as for upper secondary school potential. Moreover, we also used the same distance decay function in calculating the so called self-potential. Following Rich (1978) and Gutiérrez, Condeço-Melhorado, López, Monzón (2011), we assume that when calculating the portion of potential generated internally, the surface of the transport zone is equated to a circle, the average travel distance is half the radius, $0.5 \sqrt{\frac{a r e a}{\pi}}$, and the assumed internal travel speed, $\overline{v_{l l}}$, is $4.82 \mathrm{~km} / \mathrm{h}$, which takes into account the pedestrian speed due to the fact that the majority of pupils go to school on foot if located in their own transport zone.

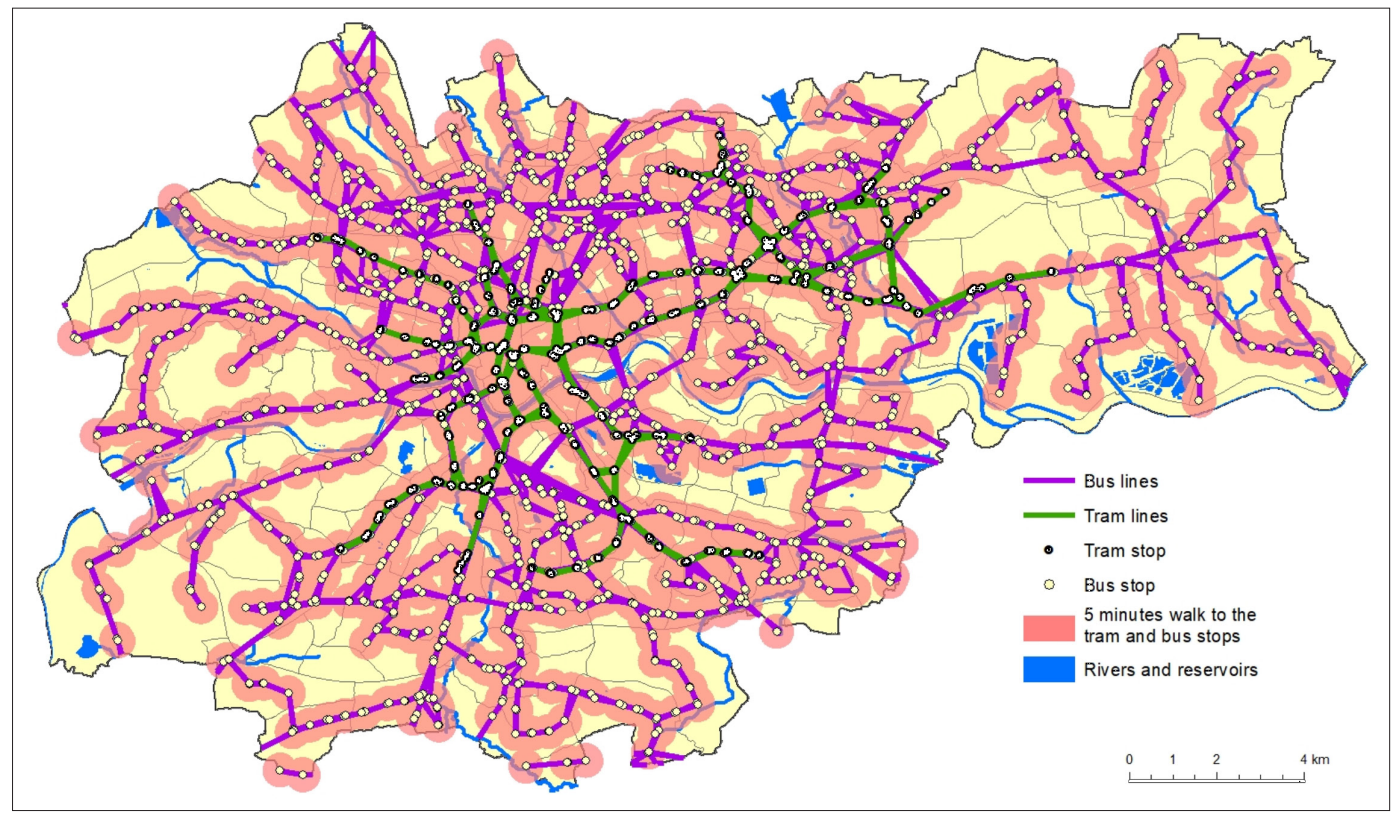

Fig. 3: Kraków public transport system - tram and bus stops within 5 minutes walking time Source: authors' analysis 
The analysis of the accessibility of upper secondary schools was conducted for each of the main types of schools independently (general upper secondary schools, technical secondary schools, basic vocational schools), as well as for all upper secondary schools together. In order to enable comparisons of the spatial differentiation of results, the total sum of results of potential accessibility indicators for the whole city was equated to 1000 for each accessibility calculation.

A similar procedure was adopted for the potential quotient analysis. For the purposes of comparative analysis, we applied the simplified version of the potential ratio assuming that the total sum of values of both nominator (educational potential) and denominator (population potential) are identical. Then, the potential quotient was calculated for each region independently. The numerical values are multiplied by 100 in the graphics, which means that if the index is higher than 100, then the educational potential exceeds the population potential, and if the index is below 100 , then the educational potential is lower.

\section{Results}

The results presented focus on the spatial aspects of the potential accessibility distribution, with particular attention given to the potential quotient, the mean centre of potential accessibility and potential accessibility dispersion index, concerning both the number of school-age pupils and upper secondary schools.

The spatial distribution of the population aged 15-19 and the pupils in upper secondary schools are generally similar to each other in Kraków. Therefore the potential accessibility pattern also looks similar both for accessibility to the population and accessibility to upper secondary schools. The most accessible areas for pupils are those located in the vicinity of schools, i.e. mainly in the city centre and northeast of the centre, as well as along tram lines and selected high-frequency bus lines.

Nowa Huta and its neighbouring districts, as the area of dominance of heavy industry including the steel industry, are characterised by a relatively higher density of technical

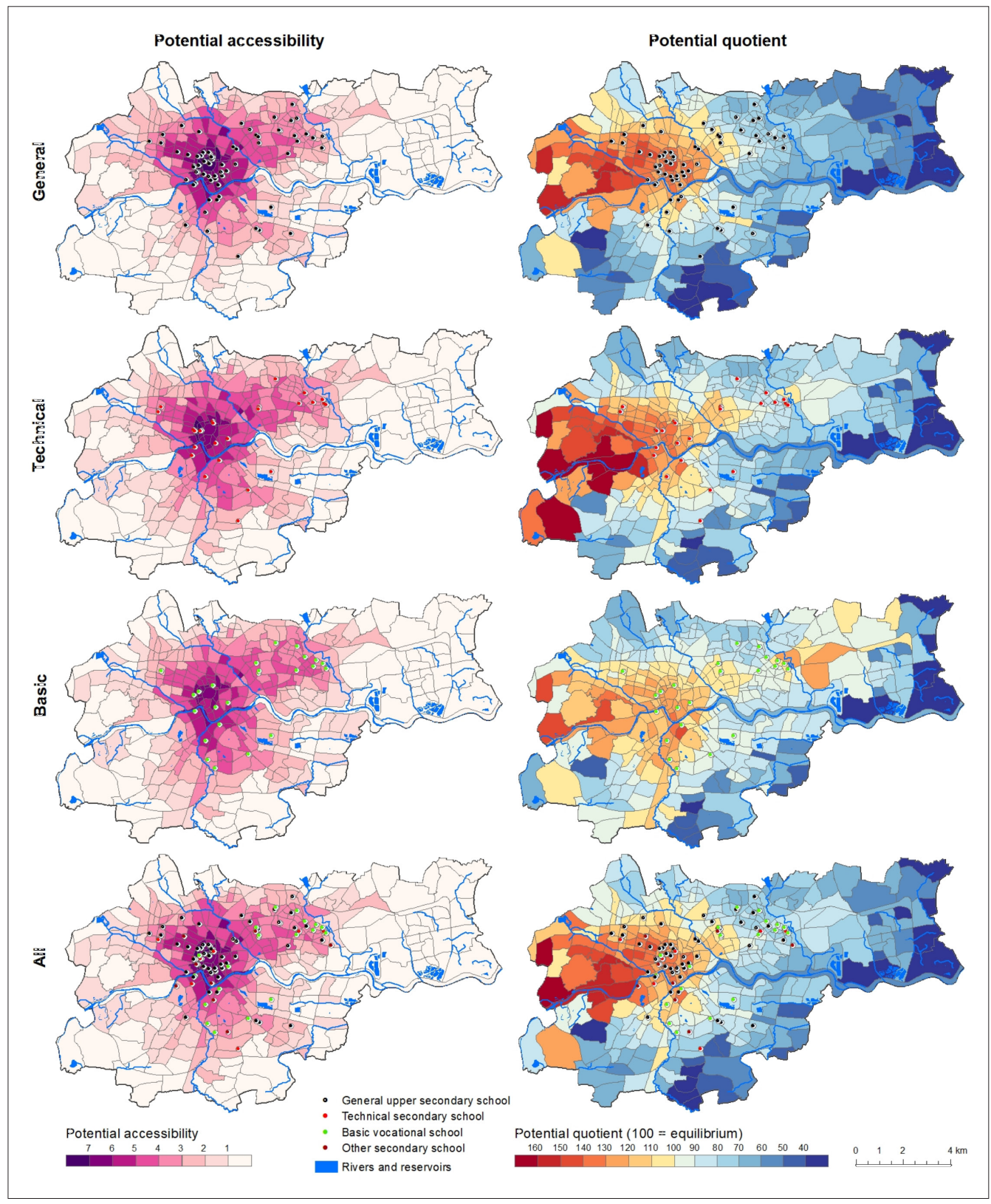

Fig. 4: Potential accessibility of different types of upper secondary school and potential quotient Source: authors' analysis 
secondary schools and, in particular, basic vocational schools. Therefore, pupils inhabiting these areas have relatively better access to the above-mentioned types of schools. The lowest level of accessibility within the boundaries of the city is found in the southern parts of Kraków and in the far eastern parts of Nowa Huta. In the case of Nowa Huta, the situation in this respect was improved by the modernisation of the tram line to Pleszów (Nowa Huta). Further improvement will be possible in the next decade if plans to build a new metro line in Krakow are implemented (east-west connections between Bronowice and Nowa Huta).

At first glance, due to the quite similar distribution pattern of population and education potential accessibility, the mean centres of both indicators are located close to each other (near the Mogilskie roundabout; see Fig. 5). Nevertheless, the results provided by the potential quotient analysis (Fig. 4), show that the surplus of upper secondary school potential over the people aged 14-19 potential is clearly visible in the western part of the city, primarily in the Zwierzyniec district. This result is confirmed by the fact that the weighted mean centre of the potential to upper secondary schools is located a little westward of the population mean. Despite the relatively large number of schools in the northeastern districts, there are usually less pupils compared with the large upper secondary schools in the city centre. Moreover, the population is more proportionately distributed between these two clusters of upper secondary schools. Thus, the eastern districts can be considered as not sufficiently equipped with secondary schools. This is similar to the southern districts, i.e. Podgórze and Swoszowice, which are rapidly growing in terms of population, and which are also characterised by a surplus of population potential over upper secondary school potential.

In terms of infrastructure investments, especially new tram lines, the city of Krakow has met expectations by launching a new tram line to Płaszów in 2010 (there are advanced plans to extend it up to the S7 eastern ringroad). Because of this investment, young people living in this district have the opportunity to travel rapidly towards the city centre, where the secondary schools are located (Jurkowski and Smolarski, 2018). Currently, the city is also carrying out an investment consisting of the construction

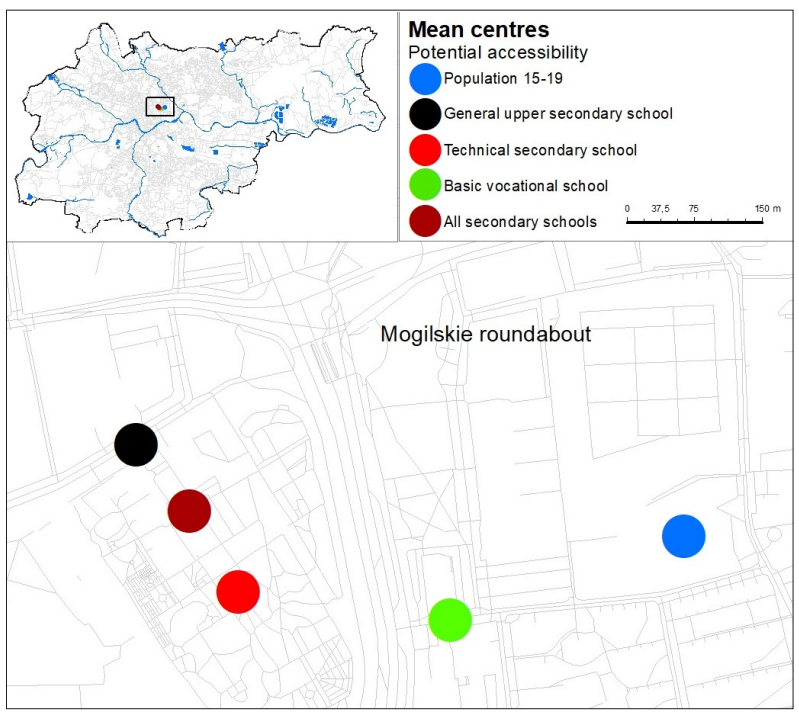

Fig. 5: Mean centres of potential accessibility of the number of school-age individuals and the different types of upper secondary schools

Source: authors' analysis of a tram line along the Łagiewnicka Route (connecting the housing estates in Kurdwanów with the Zakopiańska route), which will result in the creation of a tram ring in the southern districts of the city. Nevertheless, the location of additional upper secondary schools in the above-mentioned areas will affect the provision of more equal access to education facilities for pupils living in Kraków.

The analysis of the Potential Accessibility Dispersion (PAD) index confirms the above- mentioned results. The spatial inequality is highest for general upper secondary schools (PAD index above 0.7), while technical secondary schools and basic vocational schools seem to be more equally distributed. Nevertheless, the values do not differ a lot when compared with the PAD index for the population aged 1519 , which is an acceptable result from an educational policy point of view (see Tab. 4).

\begin{tabular}{|c|c|c|c|c|c|}
\hline \multirow{2}{*}{$\frac{\not{d}}{g}$} & \multirow{2}{*}{ 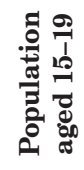 } & \multicolumn{4}{|c|}{ Upper secondary schools } \\
\hline & & General & Technical & Basic & All \\
\hline PAD index & 0.580 & 0.702 & 0.659 & 0.640 & 0.680 \\
\hline
\end{tabular}

Tab. 4: Potential accessibility dispersion (PAD) index Source: authors' analysis

\section{Conclusions}

After commuting to work, commuting to schools is the second most important travel motivation for public transport users within the city. Taking that into account, the relatively small number of studies of the accessibility of schools, in particular those at the medium level of centralisation, i.e. upper secondary schools, is quite surprising.

We conclude that local differences in the level of potential accessibility and potential quotient in the context of secondary schools should become an important premise for making decisions regarding new locations of school facilities. This is particularly important in Poland, and more broadly also in selected countries of Central and Eastern Europe, including the Czech Republic and Slovakia, where in the years to come there will be a slight increase in the group of pupils aged $15-19$.

Those cities in which selected peripheral districts had an industrial function in previous decades (as in Nowa Huta in Kraków) may suffer from an unbalanced spatial distribution of different types of schools. Therefore, it is recommended that in the future new schools should not only be located in the context of a new residential area, but also to better balance access to different types of schools throughout the city. It is in this context, that the new location of a general upper secondary school might be considered in the southern or eastern part of Kraków. Nevertheless, the picture of inequality would be a little different if the study also included the suburban zones. Similar research in the future should also take into account the population living in the entire agglomeration outside the city core and the timetables of suburban trains and buses used by pupils in their daily commuting to schools.

Moreover, it is important to consider public transport schedules adapted to the needs of commuting to/from schools in order to increase the level of accessibility (Guzik, 2003a). A fairly large variability in the level of potential quotient 
between neighbouring peripheral transport regions was observed in the morning rush hour. Thus, it is important to develop a comprehensive policy that takes into account both the spatial and temporal components of the accessibility of upper secondary schools.

Moreover, there is a need for greater emphasis on the study of the relationships between spatial policy, housing policy and transport policy, both at the city level and in its surroundings. The use of potential accessibility indicators, including also demand and supply conditions, is among the ways to speed up the planning process in the case of the provision of additional secondary schools. The potential quotient method presented can be used for accessibility monitoring and planning. By changing the number of places in schools and using forecasts of the number of lower secondary school graduates, it is possible to simulate changes in accessibility. Interpretation of the results in terms of supply and demand makes it possible to apply this methodology to studies of accessibility to other services, both on a regional, local and intra-city scale (Guzik, 2003b). The proposed method can be used to analyse differences in accessibility to various types of services, not only educational services, but also, for example, to shops, hospitals etc.

\section{Acknowledgements}

This research received funds from the National Science Centre in Poland allocated on the basis of decision No. UMO-2016/21/B/HS4/01578 "Mobility-accessibility feedback loop. Theoretical considerations (author's own NeST box model) vs. Polish spatial reality (MA-trix)" and UMO-2012/05/E/HS4/01798 "Multimodal public transport accessibility of Polish gminas". Stawomir Goliszek gratefully acknowledges the support of the Polish National Science Centre allocated on the basis of the decisions No. UMO-2017/25/N/HS4/01237 and UMO-2020/36/T/HS4/00131 both projects named "Significance of transport accessibility components in Szczecin with particular focus on collective transport in the period 2009-2018 (TraCoM)".

\section{References:}

BIOSCA, O., SPIEKERMANN, K., STEPNIAK, M. (2013): Transport Accessibility at Regional Scale. Europa XXI, 24: $5-17$.

CAVE, W., CHESTER, M. A. (1981): A sociology of education: access to power and privilege. New York, Macmillan Publishing.

CHENG, J., BERTOLINI, L. (2013): Measuring urban job accessibility with distance decay, competition and diversity. Journal of Transport Geography, 30: 100-109.

CZYŻ, T. (2002): Application of the potential model to the analysis of regional differences in Poland. Geographia Polonica, 75(1): 13-24.

DEPARTMENT FOR TRANSPORT (2005): Guidance on Accessibility Planning in Local Transport Plans. 104.

DONY, C. C., DELMELLE, E. M., DELMELLE, E. C. (2015): Re-conceptualizing accessibility to parks in multi-modal cities: A Variable-width Floating Catchment Area (VFCA) method. Landscape and Urban Planning, 143: 90-99.

GAO, Y., HE, Q., LIU, Y., ZHANG, L., WANG, H., CAI, E. (2016): Imbalance in Spatial Accessibility to Primary and Secondary Schools in China: Guidance for Education. Sustainability, 8(12): 1236.
GEURS, K., ZONDAG, B., DE JONG, G., DE BOK, M. (2010): Accessibility appraisal of land-use/transport policy strategies: More than just adding up travel-time savings. Transportation Research Part D: Transport and Environment, 15(7): 382-393.

GEURS, K. T., RITSEMA VAN ECK, J. (2001): Accessibility measures: review and applications. Evaluation of accessibility impacts of land-use transportation scenarios, and related social and economic impact. RIVM Report, 787: 1-265.

GEURS, K. T., VAN WEE, B. (2004): Accessibility measures: a literature review. Accessibility evaluation of land-use and transport strategies: review and research directions. Journal of Transport geography, 12(2): 127-140.

GODDARD, M., SMITH, P. (2001): Equity of access to health care services: theory and evidence from the UK. Social Science and Medicine, 53(9): 1149-62.

GOLISZEK, S. (2021): GIS tools and programming languages for creating models of public and private transport potential accessibility in Szczecin, Poland. Journal of Geographical Systems, 23(1): Forthcoming. Doi: 10.1007/ s10109-020-00337-z.

GOLISZEK, S., POŁOM, M., DUMA, P. (2020): Potential and cumulative accessibility of workplaces by public transport in Szczecin. Bulletin of Geography. Socioeconomic Series, 50: 133-146.

GOULD, P. R. (1969): Spatial diffusion. Commission on College Geography. Resource Paper No. 4.

GULHAN, G., CEYLAN, H., ÖZUYSAL, M., CEYLAN, H. (2013): Impact of utility-based accessibility measures on urban public transportation planning: A case study of Denizli, Turkey. Cities, 32: 102-112.

GUS (2013): Wybory ścieżki kształcenia a sytuacja zawodowa Polaków.

GUS (2018): Dojazdy uczniów do szkół zlokalizowanych w miastach wojewódzkich.

GUTIERREZ, J., CONDECO-MELHORADO, A., LOPEZ, E., MONZON, A. (2011): Evaluating the European added value of TEN-T projects: a methodological proposal based on spatial spillovers, accessibility and GIS. Journal of Transport Geography, 19(4): 840-850.

GUZIK, R. (2003a): Przestrzenna dostępność szkolnictwa ponadpodstawowego, Kraków: Instytut Geografii i Gospodarki Przestrzennej Uniwersytetu Jagiellońskiego.

GUZIK, R. (2003b): Interpretacja przestrzennej dostępności szkół ponadpodstawowych $\mathrm{w}$ oparciu o metodę ilorazu potencjału. In: Rogacki, H. [ed.]: Problemy interpretacji wyników metod badawczych stosowanych w geografii społeczno-ekonomicznej i gospodarce przestrzennej (pp. 101-110). Poznań, Wydawnictwo Naukowe Bogucki.

HALAS, M., KLAPKA, P. (2015): Spatial influence of regional centres of Slovakia: analysis based on the distance-decay function. Rendiconti Lincei. Scienze Fisiche e Naturali 26(2): 169-185.

HANSEN, W. G. (1959): How Accessibility Shapes Land Use. Journal of the American Institute of Planners, 25(2): 73-76.

JOHNSTON, R. J., GREGORY, D., SMITH, D. M. [eds.] (1994): The Dictionary of Human Geography. Oxford, Blackwell Publishers Ltd. 
JURKOWSKI, W., SMOLARSKI, M. (2018): The impact of transport supply on passenger volume characterising regional rail transport in Lower Silesia. Europa XXI, 34: 79-93.

KBR in Gdańsk (2016): Gdańskie Badania Ruchu. Gdańsk, Gdańsk Development Office.

KBR in Kraków (2013): Badania zachowań komunikacyjnych mieszkańców Krakowskiego Obszaru Metropolitarnego. Politechnika Krakowska, PBS Sp. z 0.o., Jan Friedberg Projektowanie i doradztwo w zarządzaniu, EKKOM Sp. z o.o. and International Management Services Sp. z 0.o., Kraków.

KBR in Poznań (2013): Badania i opracowanie planu transportowego aglomeracji poznańskiej, Plan transportowy aglomeracji poznańskiej. Poznań, Biuro Inżynierii Transportu. Pracownie Projektowe sp.j.

KBR in Warsaw (2015): PBS Sp. z o.o., Badanie zachowań transportowych mieszkańców Warszawy, Politechnika Krakowska and Politechnika Warszawska.

KNOX, P. L. (1978): The intraurban ecology of primary medical care: patterns of accessibility and their policy implications. Environment and Planning A: Economy and Space, 4(1): 415-435.

KUČEROVÁ, S. R., BLÁHA, J. D., KUČERA, Z. (2015): Transformations of spatial relationships in elementary education: A case study of changes in two Czech rural areas since the second half of the $20^{\text {th }}$ century. Moravian Geographical Reports, 23(1): 34-44.

KUREK, S., WÓJTOWICZ, M., GAŁKA, Z. (2015): The changing role of migration and natural increase in suburban population growth: The case of a non-capital post-socialist city (The Krakow Metropolitan Area, Poland). Moravian Geographical Reports, 23(4): 59-70.

LEE, J., LUBIENSKI, C. (2017): The Impact of School Closures on Equity of Access in Chicago. Education \& Urban Society, 49(1): 53-80.

LITMAN, T. (2008): Evaluating accessibility for transportation planning. Victoria Transport Policy Institute, Victoria, Canada.

LÓPEZ, E., GUTIÉRREZ, J., GÓMEZ, G. (2008): Measuring Regional Cohesion Effects of Large-scale Transport Infrastructure Investments: An Accessibility Approach, European Planning Studies, 16: 277-301.

LUCAS, K. (2012): Transport and social exclusion: Where are we now? Transport Policy, 20: 105-113.

MANAUGH, K., BADAMI, M. G., EL-GENEIDY, A. M. (2015): Integrating social equity into urban transportation planning: A critical evaluation of equity objectives and measures in transportation plans in North America. Transport Policy, 37: 167-176.

MARTENS, K. (2012): Justice in transport as justice in accessibility: Applying Walzer's "Spheres of Justice" to the transport sector. Transportation, 39(6): 1035-1053.

MCGRAIL, M.R. (2012): Spatial accessibility of primary health care utilising the two-step floating catchment area method: an assessment of recent improvements. International Journal of Health Geographics, 11(1): 50.

MORENO-MONROY, A. I., LOVELACE, R., RAMOS, F. R. (2018): Public transport and school location impacts on educational inequalities: Insights from Săo Paulo. Journal of Transport Geography, 67: 110-118.
NIEDZIELSKI，M. A., KUCHARSKI， R. (2019): Impact of commuting, time budgets, and activity durations on modal disparity in accessibility to supermarkets. Transportation Research Part D: Transport and Environment, 75: 106-120.

ORTEGA, E., LÓPEZ, E., MONZÓN, A. (2012): Territorial cohesion impacts of high-speed rail at different planning levels, Journal of Transport Geography, 24: 130-141.

ÖSTH, J., LYHAGEN, J., REGGIANI, A. (2016): A new way of determining distance decay parameters in spatial interaction models with application to job accessibility analysis in Sweden. European Journal of Transport and Infrastructure Research, 16(2): 344-363.

PACIONE, M. (1989): Access to urban services - the case of secondary schools in Glasgow. Scottish Geographical Magazine, 105: 12-18.

PASHKEVICH, A., PUŁAWSKA, S. (2016): Assessment of Shopping Malls Accessibility: Case Study of Kraków. In CIT2016 - XII Congreso de Ingeniería del Transporte Valčncia, Universitat Politčcnica de Valčncia.

PRITCHARD, J. P., MOURA, F., E SILVA, J. A., MARTINEZ, L. M. (2014): Spatial analysis of transportation-related social exclusion in the Lisbon metropolitan area. Procedia - Social and Behavioral Sciences, 111: 440-449.

QVISTRÖM, M. (2015): Putting accessibility in place: A relational reading of accessibility in policies for transitoriented development. Geoforum, 58: 166-173.

RICH, D. C. (1978): Population potential, potential transportation cost and industrial location. Area, 10(3): $222-226$

ROSIK, P., POMIANOWSKI, W., KOMORNICKI T., GOLISZEK, S., SZEJGIEC-KOLENDA, B., DUMA, P. (2020): Regional dispersion of potential accessibility quotient at the intra-European and intranational level. Core-periphery pattern, discontinuity belts and distance decay tornado effect, Journal of Transport Geography, 82: 102554

SALZE, P., BANOS, A., OPPERT, J. M., CHARREIRE, H., CASEY, R., SIMON, C., CHAIX, B., BADARIOTTI, D., WEBER, C. (2011): Estimating spatial accessibility to facilities on the regional scale: an extended commutingbased interaction potential model. International Journal of Health Geographics, 10(1): 2.

SCOTT, D. M., HORNER, M. W. (2008): The role of urban form in shaping access to opportunities. Journal of Transport and Land Use, 1(2): 89-119.

SIO (2016): Schools and educational institutions identification data; List of schools and educational institutions: List of schools and facilities in Małopolska data according to SIO of September 30 [online]. Available at: https://kuratorium.Kraków.pl/szkoly-i-placowkioswiatowe-dane-identyfikacyjne/

SKOV-PETERSEN, H. (2001): Estimation of distancedecay parameters-GIS-based indicators of recreational accessibility. ScanGIS, 2001(June): 237-258.

STEPNIAK, M., GOLISZEK, S. (2017): Spatio-Temporal Variation of Accessibility by Public Transport - The Equity Spatio-Temporal Variation of Accessibility by Public Transport - The Equity Perspective. In: Ivan, I., Singleton, A., Horák, J., Inspektor, T. [eds.]: The Rise 
of Big Spatial Data. Lecture Notes in Geoinformation and Cartography (pp. 241-261). Springer International Publishing.

STĘPNIAK, M., PRITCHARD, J. P., GEURS, K. T., GOLISZEK, S. (2019): The impact of temporal resolution on public transport accessibility measurement: Review and case study in Poland, Journal of Transport Geography, 75: 8-24.

STĘPIAK, M., ROSIK, P. (2016): From improvement in accessibility to the impact on territorial cohesion: the spatial approach. Journal of Transport and Land Use, 9(3): 1-13.

STĘPNIAK, M., ROSIK, P. (2018): The role of transport and population components in change in accessibility: the influence of the distance decay parameter. Networks and Spatial Economics, 18(2): 291-312.

STĘPNIAK, M., WISNIEWSKI, R., GOLISZEK, S., MARCIŃCZAK, S. (2017): Dostępność przestrzenna do usług publicznych w Polsce. IGiPZ PAN.

SZARATA, A. (2013): Modelowanie podróży wzbudzonych oraz tłumionych zmianą stanu infrastruktury transportowej. Kraków, Wydawnictwo Politechniki Krakowskiej. Seria Inżynieria Lądowa.

SZARATA, A. (2014): Kompleksowe Badania Ruchu w Krakowie w 2013 r. - wybrane wyniki. Logistyka, 6: 13798-13805.

THELIN, M., NIEDOMYSL, T. (2015): The (ir)relevance of geography for school choice: Evidence from a Swedish choice experiment. Geoforum, 67: 110-120.

TIRAN, J., LAKNER, M., DROBNE, S. (2019): Modelling walking accessibility: A case study of Ljubjana, Slovenia. Moravian Geographical Reports, 27(4): 194-206.

TSOU, K. W., HUNG, Y. T., CHANG, Y. L.(2005): An accessibility-based integrated measure of relative spatial equity in urban public facilities. Cities, 22(6): 424-435.

VAN WEE, B., GEURS, K. (2011): Discussing equity and social exclusion in accessibility evaluations. European Journal of Transport and Infrastructure Research, 11(4): 350-367.

VAN WEE, B., HAGOORT, M., ANNEMA, J. A. (2001): Accessibility measures with competition. Journal of Transport Geography, 9(3): 199-208.

WALASZEK, M. (2006): Dostępność przestrzenna szkół oraz warunki i wyniki nauczania w aglomeracji poznańskiej, Poznań, Bogucki Wydawnictwo Naukowe.
WALASZEK, M. (2016): Zasięg oddziaływania szkolnictwa ponadgimnazjalnego na przykładzie miasta Poznania Spatial Range of Secondary Education on the Example of Poznan Marzena Walaszek. Studia Oeconomica Posnaniensia, 4(6): 129-146.

WAN, N., ZOU, B., STERNBERG, T. (2012): A three-step floating catchment area method for analyzing spatial access to health services. International Journal of Geographical Information Science, 26(6): 1073-1089.

WANG, C. H., CHEN, N. (2015): A GIS-based spatial statistical approach to modeling job accessibility by transportation mode: Case study of Columbus, Ohio. Journal of Transport Geography, 45: 1-11.

WEGENER, M., KVĚTOŇ, V., MARADA, M., SCHÜRMANN, C., BIOSCA, O., SEGUI, A. U., ANTIKAINEN, H., KOTAVAARA, O., RUSANE, J., BIELAŃSKA, D., FIORELLO, D., KOMORNICKI, T., ROSIK, P., STĘPNIAK, M. (2015): TRACC - Transport Accessibility at Regional/Local Scale and Patterns in Europe. European Spatial Planning Observation Network - ESPON, 2: 264.

WEIBULL, J.W. (1976): An axiomatic approach to the measurement of accessibility. Regional Science and Urban Economics, 6(4): 357-379.

WIDENER, M. J., FARBER S., NEUTENS T., HORNER M. W. (2013): Using urban commuting data to calculate a spatiotemporal accessibility measure for food environment studies. Health and Place, 21: 1-9.

WIĘCKOWSKI, M., SAARINEN J. (2019): Tourism transitions, changes, and the creation of new spaces and places in Central-Eastern Europe. Geographia Polonica, 92(4): 369-377.

WILLIAMS, S., WANG, F. (2014): Disparities in accessibility of public high schools, in metropolitan Baton Rouge, Louisiana 1990-2010. Urban Geography, 35(7): 10661083.

YE, C., ZHU, Y., YANG, J., FU, Q. (2018): Spatial equity in accessing secondary education: Evidence from a gravitybased model. Canadian Geographer, 62(4): 452-469.

ZELINSKY, T., KUBAK, M. (2014): Distance to Education and Health Services by Pupils from Marginalized Roma Communities. Central European Conference in Regional Science CERS 2014: 1180-1187.

\section{Please cite this article as:}

ROSIK, P., PUŁAWSKA-OBIEDOWSKA, S., GOLISZEK, S. (2021): Public transport accessibility to upper secondary schools measured by the potential quotient: The case of Kraków. Moravian Geographical Reports, 29(1): 15-26. Doi: https://doi.org/10.2478/mgr-2021-0002 